\title{
Perceived Climate Change Impacts and Adaptation Strategy of Indigenous Community (Chepangs) in Rural Mid-hills of Nepal
}

\author{
Pragya Khanal1 ${ }^{*}$, Bishnu H. Wagle1, Suraj Upadhaya², Prayash Ghimire ${ }^{3}$ \\ and Suman Acharya ${ }^{4}$
}

\begin{abstract}
Climate change is projected to increase in vulnerable areas of the world, and marginalized communities residing in rural areas are more vulnerable to the change. The perceptions of climate change and adaptation strategies made by such communities are important considerations in the design of adaptation strategies by policy-makers. We examined the most marginalized indigenous group "Chepang" communities' perceptions towards this change, variability, and their attitudes to adaptations and adapted coping measures in mid-hills of Nepal. We interviewed 155 individuals from two Chepang communities, namely, Shaktikhor and Siddhi in Chitwan district of Nepal. We also analyzed biophysical data to assess the variability. The findings showed that the Chepang community has experienced significant impacts of climate change and variability. They attributed crop disease, insect infestation, human health problem, and weather-related disaster as the impacts of climate change. Strategies they have adopted in response to the change are the use of intense fertilizers in farmland, hybrid seeds cultivation, crop diversification, etc. Local level and national level adaptation policies need to be designed and implemented as soon as possible to help climate vulnerable communities like Chepangs to cope against the impacts of climate change.
\end{abstract}

Keywords: Climatic variability, peoples' perceptions, attitudes to adaptations, adapted coping measures, indigenous people

Khanal, P., Wagle, B.H., Upadhaya, S., Ghimire, P., Acharya, S. (2019): Perceived Climate Change Impacts and Adaptation Strategy of Indigenous Community (Chepang) in Rural Mid-hills of Nepal. Forestry: Journal of Institute of Forestry, Nepal. No. 17: page 48 to 61.

${ }^{1}$ Institute of Forestry, Pokhara, Nepal

*Corresponding Author, email: prajnakhanal@gmail.com

${ }^{2}$ Department of Natural Resource Ecology and Management, Iowa State University, Ames, IA, 50011, USA

${ }^{3}$ Agriculture and Forestry University, Hetauda, Nepal

${ }^{4}$ Department of Anthropology, University of Maine, Orono, ME, USA 


\section{Introduction}

Although Nepal's contribution to global greenhouse gas emissions is very low, it is considered to have an extremely high risk of climate change (Gentle, Maraseni 2012; Godar Chhetri 2012). Moreover, Nepal is recognized to be the fourth most climate-vulnerable nation in the present world (Adhikari et al. 2018; Gentle et al. 2014). Categorized under least developed country, Nepal comprises of ample agriculture and resources dependent communities including Chepang, Rai, Tamang, etc. in rural hills which are highly vulnerable to the adverse impacts of climate change (Piya et al. 2016).

More than $80 \%$ of Nepalese communities depend on agriculture for their livelihood and fall under poverty. Although Chepang community was considered to be a nomadic indigenous community as they were dependent on hunting and gathering earlier, currently, they are dependent on rain-fed agricultural system and forest resources for their subsistence and livelihood (Piya et al. 2016). In developing nations such as Nepal, marginalized communities dependent on natural resources for their livelihood are facing more impacts of climate change and are susceptible to climatic vulnerability, and at the same time, these communities are deprived of adaptation practices because of multitude barriers where cultural barrier is a major one (Adger et al. 2013). Chepangs are thus, grouped as highly marginalized indigenous communities facing multiple impacts of climate change and lacking knowledge on adaptation strategies to cope with changing climate (Piya et al. 2013). A larger number of Chepang communities are residing in the mid-hills of Central Nepal. Although residents from diverse communities are facing detrimental impacts of climate change, Piya et al. (2013) reported that Chepang communities are considered as one of the highly climate vulnerable communities in Nepal, and are facing major impacts like unpredictable droughts and erratic rainfall that have led to the reduction of agricultural products. For instance, maize and millet production in their communities are dramatically fluctuating and declining. Similarly, they have been the victim of acutely rising temperature, unexpected change in seasons, significant reduction in agricultural productivity, water shortage, etc., which have resulted to increaseimpacts of climate change, because, they are agriculture dependent and residing in rural mountain landscape (Halbrendt et al. 2014; Piya et al. 2013, 2016). Moreover, indigenous, marginal and socially excluded communities like Chepangs with low physical and social assets and adaptive capacity to cope with the changing climate are facing remarkable impacts of climate change (Pandey et al. 2016; Piya et al. 2016).

In response to these increasing impacts of climate change, Nepal has been successful in preparing various environmental policies, and has tried to implement them. Different adaptation policies like Climate Change Policy, 
National Adaptation Programs of Actions (NAPA), Local Adaptation Plans for Actions (LAPA) and Forest Policy have been formulated and implemented in different timeframe that have made some changes in rural adaptation initiatives (Dhungana et al. 2018; Gauli, Upadhaya 2014; Gentle et al. 2018; Ghimire et al. 2019). However, indigenous communities like Chepangs still lack minimal knowledge about climate change adaptation (Halbrendt et al. 2014; Piya et al. 2013). They are adopting some sorts of climate change adaptation like practices without clear knowledge of what they are doing, and are considered to be autonomous and short-term practices. These sorts of adaptation practices could turn out to be maladaptive practice in the near future. Lack of education, poor social networks, poor economic status and settlement in geographically poor landscapes, incapability of information and lower adaptive capacity are the prime reason that they are unable to adopt adaptation strategies (Halbrendt et al. 2014; Piya et al. 2013). There is, thus, the lack of scientific information on the impacts of climate change and the adaptation strategies that the indigenous and marginalized Chepang community is adopting in response to the changing climate. This study looked into the perception of the Chepang community towards climatic variability, impacts of climate change in their community, and adaptation practices adopted by Chepangs in response to climate change at present. The information from this study feeds into the formulation of national climate change policy as it will provide a better idea on climate change impacts and adaptation strategies that some marginalized indigenous communities such as Chepangs and others could adapt based upon their traditional ecological knowledge. The study adopted descriptive and exploratory research design. Problems identified into the field were analysed and described based on its functions and conditions. There has been limited research into climate change impacts on chepang community, and this research tries to explore the problems.

\section{Chepangs: the Study Community}

The Chepangs are one of the many indigenous nationalities of Nepal with a population of 52,237 (0.23\% of the total population of Nepal) (CBS 2011). Majority of this community live in mid-hills in Chitwan, Makawanpur, Dhading and Gorkha districts of Nepal. The Chepang community has been categorized as a highly marginalized indigenous nationality by the government of Nepal. Although Chepangs depend on agriculture, their major livelihoods rely on forest resources to a large extent for wild edibles, fodder and fuel. As Chepangs' livelihoods are mainly based on natural resources, they are likely to suffer from the impacts of climate change such as variability in rainfall, drying up of water resources, etc. Piya et al. (2016) mentioned that Chepang's vulnerability is further compounded by limited access to information and by spatial isolation, and suggested that studies investigating vulnerability to climate change should focus on marginalized communities because they are the most vulnerable and least 
able to cope with the adverse impacts. To draw the attention of the government and stakeholders to these issues, it is necessary to gather information through studies based on the livelihoods of these vulnerable communities. With this in mind, we purposively selected Chepang community for this study.

\section{Materials and Methods}

\section{Study Area}

Chitwan district lies in Siwalik range of central development region of Nepal. The geographical position of the district lies between latitude $27^{\circ} 21^{\prime} \mathrm{N}$ to $27^{\circ} 46^{\prime} \mathrm{N}$ and longitude $83^{\circ} 55^{\prime} \mathrm{E}$ to $84^{\circ} 48^{\prime} \mathrm{E}$. The district is characterized by the fragile land topography with Churiya hills and altitude ranging from $141 \mathrm{~m}$ to $1945 \mathrm{~m}$ above mean sea level. Chepangs mainly reside in Kaule, Korak, Siddhi, Ayodhyapuri and Shaktikhor VDCs of Chitwan district (CBS 2011). Therefore, Shaktikhor and Siddhi, which are known as pocket villages of the Chepangs are selected as study area (Figure 1).

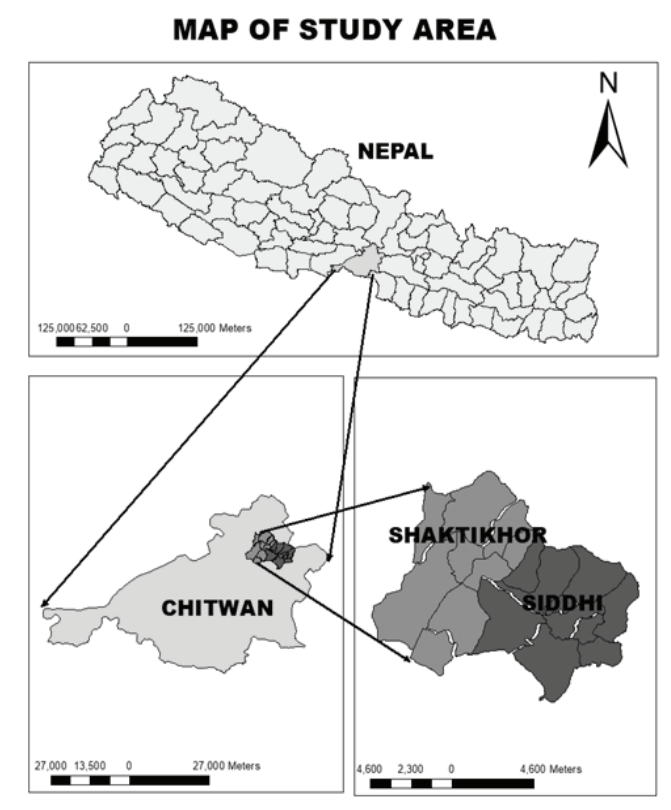

Figure 1 : Location Map of the Study Area

\section{Methods}

\section{Data Sources}

The study was based on primary data collected throughthe household survey. More than 5\% constituting a total of 155 households (79 from Shaktikhor and 76 from Siddhi VDC) were randomly selected as sample households for interview. The survey contained a set of questionnaires that mainly focused on capturing the perception of selected households on climate change, its impacts and adaptation as well as their coping strategies to address the impacts.

In addition to the household survey, we conducted key informants survey and focus group discussions to gather in-depth information and to understand the situation more. The community leaders, Community Forest Users' Groups secretaries, local teachers, ward committee members and the members of local Community Based Organizations (CBOs) were selected as key informants. We 
conducted two focus group discussions, one in each VDCwhich included elite representatives of the community (15 individuals in each discussion). The focus group discussion was guided by the set of questionnaires. In addition to this, we let discussion to be free so that we would not miss any information that was not covered by the questionnaire. The discussion was further helpful to enrich and verify the information received through the household survey and key informant interview.

To understand the impacts of climate change in the area, different indicators of impacts, such as agricultural production, crop disease, insect infestation, animal disease, physical loss, human health, forest fire, weather-related disaster, water resource depletion and invasive species were taken. Respondents were asked to explain the current situation of each sector comparing it with the situation in the past ten years. The household survey used a five-point Likert scale, where one denoted "highly increased" and five denoted "highly decreased" to quantify people's perceptions about the temporal difference on the conditions. Responses were analyzed by computing weighted mean depending upon their preference.

This study also used raw daily data of the minimum and maximum temperature, and precipitation of Rampur station obtained from the Department of Hydrology and Meteorology, Kathmandu, Nepal for 30 years from 1987 to 2016. The data were corrected to manage the missing data. The trends of temporal variation of temperature and precipitation were analyzed using linear regression. The linear trends between time series and climatic data are as given in equation below:

$\mathrm{Y}=\mathrm{a}+\mathrm{bx}$,

Where, $\mathrm{y}=$ time (year), $\mathrm{x}=$ temperature or precipitation and "a" and "b" are constants.

\section{Results and Discussions}

Among the surveyed 155 households female represented 54\%, and the majority of the respondents were of age between 35-55 years. The education status of the respondents ranged from illiterate to bachelor level with illiterate being dominant (Table 1). The significant representation of adult age group with a wider range of education and dominance of female gave us a good opportunity to understand the impacts and adaptation strategies of climate change in the study area as the majority of household works are conducted by female members in the area. The reason behind high representation of female in our household survey was because majority of the males were not at home during the survey. In the Chepang community, it is common for the female to work at home, and male doing outside activities for livelihoods. 


\section{Table 1 : Socio-demographic Information of the Respondents}

\begin{tabular}{ll}
\hline Characteristics & Percentage (n= 155) \\
\hline Gender & 46 \\
Male & 54 \\
Female & \\
Age group & 38 \\
Young (<35 years) & 45 \\
Adult (35-55 years) & 17 \\
Elderly ( $\geq 55$ years) & \\
Education & 1 \\
Bachelors & 2 \\
Higher secondary & 13 \\
Secondary & 37 \\
Literate/primary level & 47 \\
Illiterate & \\
Primary livelihood strategy & \\
Agriculture & 98 \\
Business & 1 \\
Service & 1 \\
\hline
\end{tabular}

It was found that majority of the Chepangs were not familiar with the term "climate change", and only 30\% respondents were familiar with it. These limited people within the Chepang community aware of climate change, are the major source of information for the wider communication. Although these limited people knew the term 'climate change,' the majority of the Chepang community were found to have observed changes in temperature and rainfall patterns over the years. Similar results were reported by (Piya et al. 2012).

\section{Variability in Temperature and Precipitation: What Chepangs Perceived}

The meteorological data showed variability in the temperature trend (Figure 2). Further analysis revealed an increase in summer temperature and a decrease in winter temperature. Similarly, 77\% respondents perceived that they experienced an increase in summer temperature whereas $23 \%$ observed no change, and it was as before. Similarly, more than $46 \%$ respondents observed cooler winter compared to earlier years (Figure 3). Piya et al. (2012) also found that $47.5 \%$ of Chepang respondents in mid-hills of Nepal reported the rise in summer temperature. 


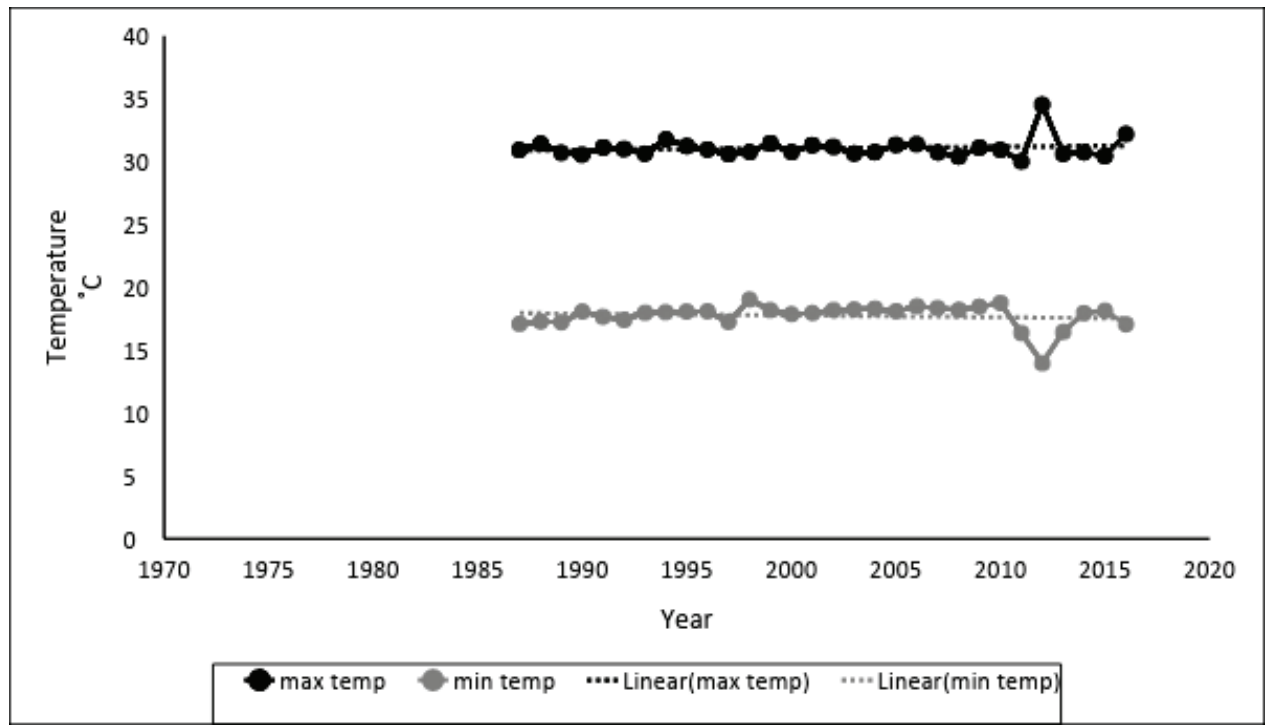

Figure 2 : Average Annual Trend of Minimum-Maximum Temperature from 1987 to 2016 at Rampur Station

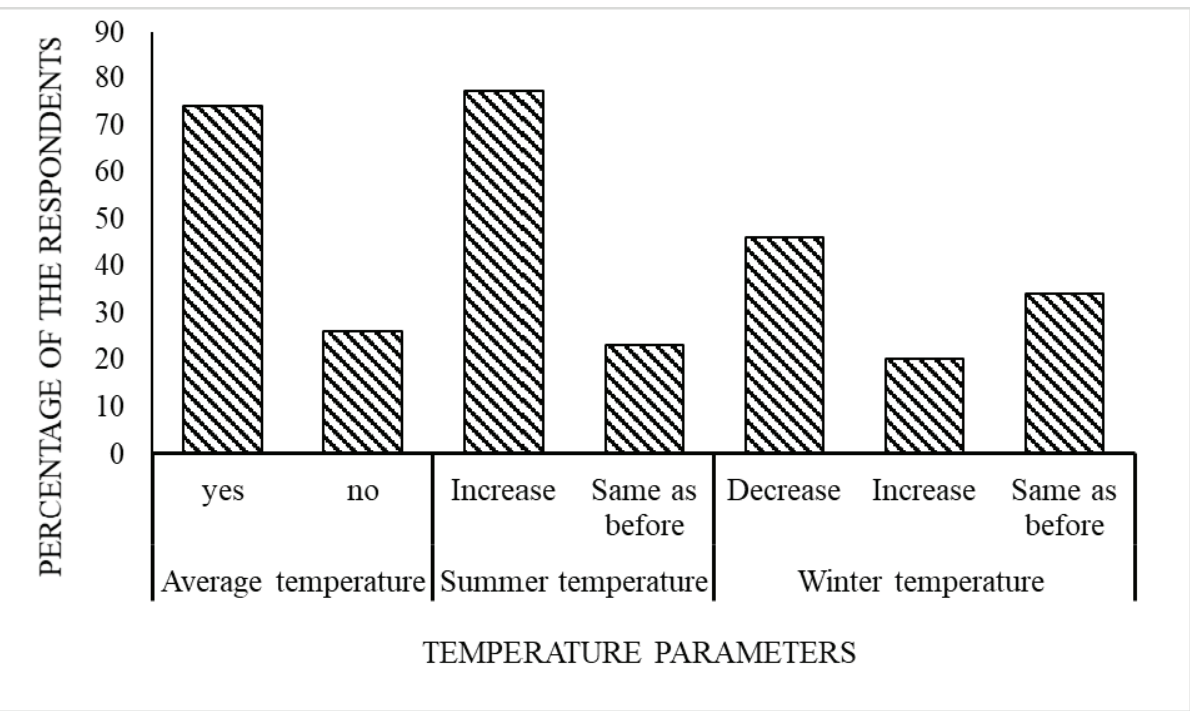

Figure 3 : Perception of Chepang Community towards Variability in

\section{Temperature}

More than $84 \%$ respondents reported that they had experienced variability in rainfall while the rest did not observe any change. Majority of them (74\%) observed an increase in rainfall. They also reported that the summer rainfall had increased (Figure 4). Our results agreed with the result reported by Poudel, 
Shaw (2016) where they found an increase in summer rainfall in Lamjung district. This perceived rainfall variability was verified by the observed meteorological data, which showed that the average annual precipitation increased by $2.11 \mathrm{~mm}$ in 30 years interval (1987-2016) (Figure 5). Although, the majority of the respondents observed variability in annual rainfall, there was great variation in responses regarding starting time of monsoon rainfall. Nearly half $(46 \%)$ of the respondents observed late rainfall, while $34 \%$ respondents observed no change, few of them (13\%) observed early rainfall and very few $(7 \%)$ observed variation in rainfall starting period. Similar results in the variation in rainfall and respondent's perception were reported by Tiwari et al. (2010). The perception of the variability of rainfall by respondents relied a lot on how they were affected by the rainfall for agriculture.

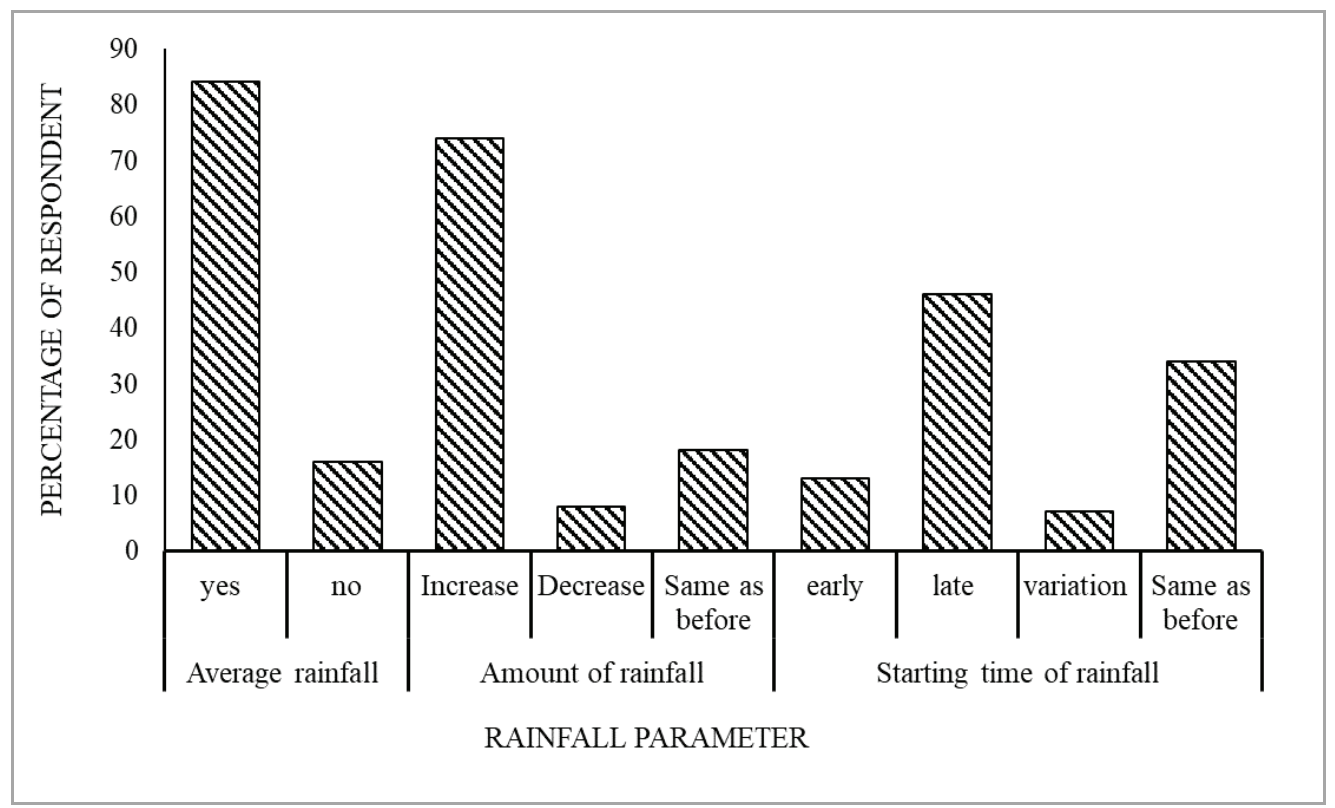

Figure 4 : Perception towards Variability in Precipitation over Different Perception Parameters 


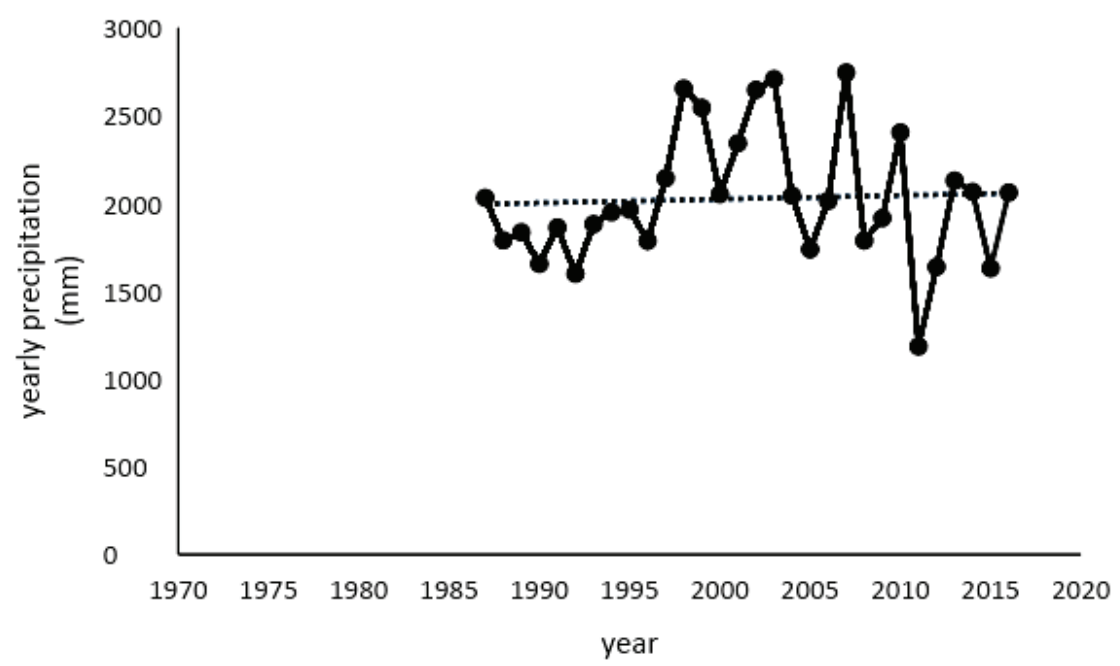

Figure 5 : Annual Variation in Precipitation from 1987 to 2016 at Rampur Station

\section{Perceived Impacts of Climate Change}

The study showed that Chepang community perceived increase in human disease as the major impacts of climate change followed by animal disease, weather-related disaster, physical loss, decrease in agricultural production, increase in crop disease/insect infestation, decrease in water resources and decrease in forest fire (Table 2). Agriculture was the primary source of livelihoods of more than $89 \%$ respondents. Paddy, maize, millet, buckwheat, black gram and mustard were the major crops grown by Chepang communities in the study area. Agriculture is mainly rainfed based, and because of this, they are more vulnerable to climate change. However, 59\% respondents observed a slight increase in agricultural production compared to 10 years ago. This might be because of the use of hybrid seeds, improved technology, and change in agricultural practices done by present Chepangs compared to 10 years back as majority of them used to farm in high slopes.

Similarly, Chepangs perceived early flowering of the tree crop, Diploknema butyraceae (Chiuri). 67\% noticed early flowering by a month. Malla (2013) reported similar results where early flowering was attributed to an increase in temperature. Respondents also perceived an increase in invasive species. Mooney and Hobbs (2000) reported that climate change influenced all invasive species by affecting their spread in a new habitat. However, forest fire occurrence was observed to have decreased compared to 10 years ago. This decrease in fire occurrence was attributed to the result of the successful establishment of community forestry program and awareness among people. 
The decrease in water availability as an impact of climate change was perceived by the majority of the respondents where this indicator obtained the weighted mean of 3.62 (Table 2). The respondents reported the decrease in the availability of drinking water in comparison to 10 years before, and highlighted the problem of fetching water from far away. They also reported drying up of existing springs and water taps. Similarly, Piya et al. $(2013,2016)$ and Gentle et al. (2014) reported that climate change impacts like reduction in agricultural productivity, increase in death of livestock due to increased incidences of diseases, increase in pests and diseases in agricultural crops, drying up of water resources used for drinking and irrigation, excessive increase in invasive species and frequently occurring disasters like landslide, erosion and flood are the major impacts prevailing in different parts of the nation.

Climatic hazards were perceived as the major impacts of climate change by the majority of respondents. We grouped climatic hazards into floods, thunderstorm, hailstorm, intense rainstorm, drought and landslide. 94\% respondents reported an increase in climatic hazards. Among them, landslide was the top one followed by drought, flood, hailstorm and intense rainstorm. These hazards might not be completely due to climate change but due to the long-term events with complex causes as explained by Khatri et al. (2016). The road construction, establishment of a poultry farm and querying in slopy lands might have triggered landslides directly, and climate change has also played crucial role for its intensification. It was reported that these hazards brought impacts on livelihoods of the local Chepangs specifically through loss of agricultural land.

Table 2 : Perceived Impacts of Climate Change on Various Indicators

\begin{tabular}{|c|c|c|c|c|c|c|}
\hline \multirow[b]{2}{*}{ Area of Impacts } & \multicolumn{5}{|c|}{ Conditions inComparison to 10 Years Ago } & \multirow[b]{2}{*}{$\begin{array}{l}\text { Weighted } \\
\text { mean }\end{array}$} \\
\hline & \begin{tabular}{|c|} 
Highly \\
increased \\
$(1)$
\end{tabular} & \begin{tabular}{|c|} 
Slightly \\
increased \\
$(2)$
\end{tabular} & $\begin{array}{c}\text { Same as } \\
\text { before } \\
\text { (3) }\end{array}$ & \begin{tabular}{|c|} 
Slightly \\
decreased \\
$(4)$
\end{tabular} & $\begin{array}{c}\text { Highly } \\
\text { decreased } \\
\text { (5) }\end{array}$ & \\
\hline $\begin{array}{l}\text { Agricultural } \\
\text { production }\end{array}$ & 26 & 91 & 23 & 9 & 6 & 2.21 \\
\hline $\begin{array}{l}\text { Crop disease/insect } \\
\text { infestation }\end{array}$ & 14 & 95 & 40 & 3 & 3 & 2.26 \\
\hline Animal disease & 42 & 87 & 24 & 1 & 1 & 1.916 \\
\hline Physical loss & 38 & 76 & 38 & 3 & 0 & 2.038 \\
\hline Human disease & 54 & 74 & 19 & 2 & 6 & 1.91 \\
\hline Forest fire & 0 & 10 & 8 & 9 & 128 & 4.64 \\
\hline $\begin{array}{l}\text { Weather related } \\
\text { disaster }\end{array}$ & 21 & 102 & 30 & 2 & 0 & 2.08 \\
\hline Water resource & 1 & 24 & 39 & 60 & 31 & 3.61 \\
\hline
\end{tabular}




\section{Local Adaptation Strategy}

The majority ( $83 \%$ ) of households are carrying out local adaptation strategy at their household level to reduce the impacts of climate change. Gentle et al. (2018) and Khanal et al. (2018) also reported that most of the adaptive strategies to reduce the loss of agricultural productivity were locally designed and implemented at household levelas short-term strategies. The major adaptation strategies were classified as the plantation of cash crops, shift to other income generation activities (IGAs), use of hybrid seeds, irrigation, intense fertilizer and practice of soil conservation activities (Figure 6). 38\% respondents reported that they cultivated fruits and vegetables instead of crops considering the possibilityto sell these in the market. However, the level of cultivation was at subsistence level. It was also found that $31 \%$ respondents shifted from agricultural production to other income generation activities, such as daily wages, business, and foreign employment. More than $48 \%$ respondents used intense fertilizers to increase agricultural production. A total of $69 \%$ of respondents have adopted soil conservation activities to reduce the soil loss from the agricultural land. Those activities varied from biological measures toengineering structures with the support of local development bodies and NGOs. However, plantation activities have been doneat the individual level. Apart from these adaptation strategies, Chepangs also reported that they had been buying food from the market, gathered wild plants and tubers from forests to support their livelihoods. The results are consistent with Gentle, Maraseni (2012), Piya et al. (2013), Gentle et al. (2018) and Khanal et al. (2018) that the vulnerable communities in different parts of Nepal have adopted different forms of adaptation strategies like use of fertilizers, crop diversification, income diversification, collection of remittance and adoption of soil conservation strategies that included both engineering and bioengineering strategies to cope with the adverse impacts of climate change and sustain their livelihood.

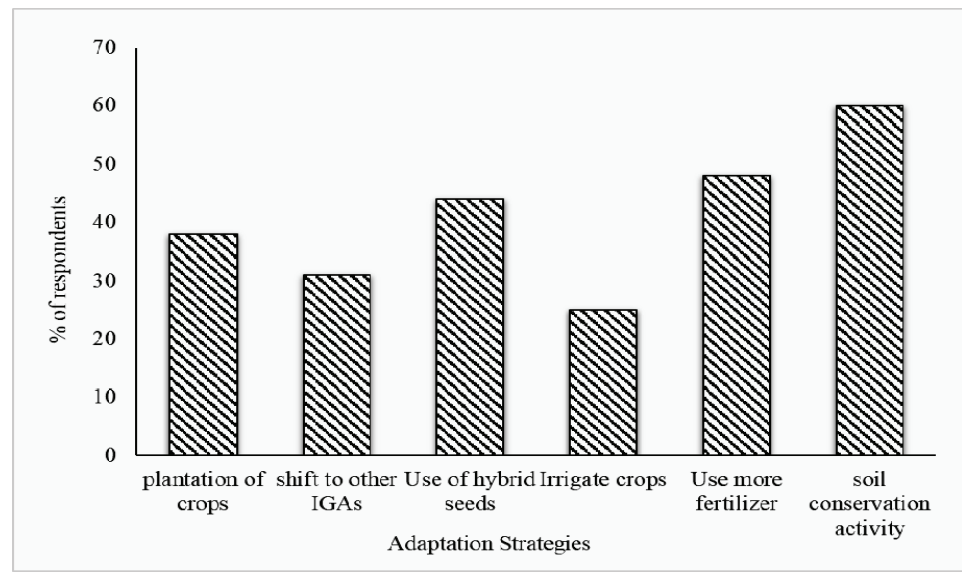

Figure 6 : Adaptation Strategies Adopted by Chepang Community in Response to Climate Change 


\section{Conclusions and Policy Implications}

This study suggests that the marginalized indigenous groups, specifically Chepangs in rural Nepal, are facing severe impacts of climate change. Regardless of their socio-economic and demographic status, they have adopted different measures in response to the adverse effects of the changing climate.Regardless of whether or not they were familiar to the term "Climate Change"they have experienced changes in amount and pattern of rainfall and variability in temperature.The increase in summer temperature and decrease in winter temperature as perceived by them was validated by the results obtained from analysis of meteorological data.

Decrease in agricultural production, increase in animal and human disease and increase in invasive speciesare among the most prevalent impacts of climate change that have severely affected the livelihoods of Chepangpeople in the study area. To reduce such impacts, Chepang community are adopting different strategies that include use of more fertilizers in agriculture, adopting income generation activities, using improved seed varieties and practicing soil conservation activities. They believed that these strategies have helped them to cope with adverse impact ofthe climate change. However, for the livelihood to be more sustainable, it is necessary to improve their social and physical assets. Providing saving and credit facility can strengthen the social cohesion and institutional capacity of such vulnerablegroups. Moreover, lobbying at policy level to focus on these groups while designing and implementing the climate change adaptation policies and strategiesis essential to strengthen these groups.

\section{Acknowledgment}

Authors like to acknowledge WWF-Nepal for providing financial support to accomplish this study. 


\section{Literature Cited}

Adger, W.N., Barnett, J., Brown, K., Marshall, N., O'Brien, K. (2013): Cultural dimensions of climate change impacts and adaptation. Nat. Clim. Change, 3: 112-117. https://doi.org/10.1038/nclimate1666

Adhikari, S., Baral, H., Nitschke, C. (2018): Adaptation to climate change in Panchase Mountain Ecological Regions of Nepal. Environments, 5: 42. https://doi.org/10.3390/environments5030042

CBS. (2011): National Population and Housing Census 2011. Central Bureau of Statistics, Nepal.

Dhungana, N., Silwal, N., Upadhaya, S., Regmi, S.K., Adhikari, S. (2018): Local people's perception and awareness of climate change: A case study from community forests in Lamjung district, Western Nepal. Banko Janakari, 28: 60-71. https://doi.org/10.3126/banko.v28i2.24189

Gauli, B., Upadhaya, S. (2014): Reducing emissions from deforestation and forest degradation (REDD) in Nepal: A review. Initiat., 5: 75-83.

Gentle, P., Maraseni, T.N. (2012): Climate change, poverty and livelihoods: Adaptation practices by rural mountain communities in Nepal. Environ. Sci. Policy, 21:24-34. https://doi.org/10.1016/j.envsci.2012.03.007

Gentle, P., Thwaites, R., Race, D., Alexander, K. (2014): Differential impacts of climate change on communities in the middle hills region of Nepal. Nat. Hazards, 74: 815-836. https://doi.org/10.1007/s11069-014-1218-0

Gentle, P., Thwaites, R., Race, D., Alexander, K., Maraseni, T. (2018): Household and community responses to impacts of climate change in the rural hills of Nepal. Clim. Change, 147: 267-282. https://doi.org/10.1007/s10584-017$\underline{2124-8}$

Ghimire, S., Dhungana, N., Upadhaya, S. (2019): Impacts of climate change on water availability and reservoir based hydropower. J. For. Nat. Resour. Manag., 1:52-68. https://doi.org/10.3126/jfnrm.v1i1.22653

GodarChhetri, S. (2012): Climate Change, its Impacts on Rural Livelihood: Adaptation Strategies from Siwalik to Terai Region. Lambert Academic Publishing, Mauritius.

Halbrendt, J., Kimura, A.H., Gray, S.A., Radovich, T., Reed, B., Tamang, B.B. (2014): Implications of conservation agriculture for men's and women's workloads among marginalized farmers in the central middle hills of Nepal. Mt. Res. Dev., 34: 214-222. https://doi.org/10.1659/MRDJOURNAL-D-13-00083.1 
Khanal, U., Clevo, W., Boon, L., Viet-Ngu, H. (2018): Smallholder farmers' participation in climate change adaptation programmes: Understanding preferences in Nepal. Climate Policy, 18(7): 916-927. https://doi.org/10.1080/14693062.2017.1389688

Khatri, D.B., Pain, A., Ojha, H., Adhikari, B., Dhungana, H. (2016): Climate Change, Local Politics and Institutional Responses in Nepal: A Synthesis Of Research Findings. Forest Action, Kathmandu.

Malla, G. (2013): Climate change and its impacts on Nepalese agriculture. J. Agric. Environ., 9: 62-71. https://doi.org/10.3126/aej.v9i0.2119

Mooney, H.A., Hobbs, R.J. (2000): Invasive Species in a Changing World. Island Press, Washington, D.C.

Pandey, S.S., Cockfield, G., Maraseni, T.N. (2016): Assessing the roles of community forestry in climate change mitigation and adaptation: A case study from Nepal. For. Ecol. Manage., 360: 400-407. https://doi.org/10.1016/j.foreco.2015.09.040

Piya, L., Joshi, N.P., Maharjan, K.L. (2016): Vulnerability of Chepang households to climate change and extremes in the mid-hills of Nepal. Climatic Change, 135(3-4): 521-537.

Piya, L., Maharjan, K.L., Joshi, N.P. (2012): Perceptions and realities of climate change among the Chepang communities in rural mid-hills of Nepal. Journal of Contemporary India Studies: Space and Society, Hiroshima University, 2: 35-50.

Piya, L., Maharjan, K.L., Joshi, N.P. (2013): Determinants of adaptation practices to climate change by Chepang households in the rural Mid-Hilss of Nepal. Regional Environmental Change, 13(2): 437-447.

Poudel, S., Shaw, R. (2016): The relationships between climate variability and crop yield in a mountainous environment: A case study in Lampung district, Nepal. Climate, 4.

Tiwari, K.R., Awasthi, K.D., Balla, M.K., Sitaula, B.K. (2010): Local people's perception on climate change, its impact and adaptation practices in Himalaya to Terai regions of Nepal. Retrieved December 29, 2011, http://repo sitory.unm.edu/bitstream/ handle/1928/11324. 